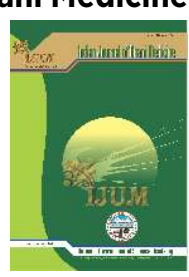

\title{
DESCRIPTION OF STOMATITIS IN THE LIGHT OF UNANI SYSTEM OF MEDICINE
}

\author{
Khan Maherosh', Mushtaque Mukadam², A.H. Farooqui ${ }^{3}$, \\ Mohd Furqan', Salma Shaikh ${ }^{5}$ and Tausif S Khan ${ }^{6}$
}

${ }^{1}$ P.G. Scholar, Department of Moalijat, ZVM Unani Medical College and Hospital, Pune, Maharashtra, India ${ }^{2}$ Assistant Professor, Department of Moalijat, ZVM Unani Medical College and Hospital, Pune, Maharashtra, India ${ }^{3}$ HOD of Moalijat, ZVM Unani Medical College and Hospital, Pune, Maharashtra, India

${ }^{4}$ Assistant Professor, Department of Amraz-e-Atfal ZVM Unani Medical College and Hospital, Pune, Maharashtra, India

${ }^{5}$ P.G Scholar, Department of Moalijat, ZVM Unani Medical College and Hospital, Pune, Maharashtra, India

${ }^{6}$ HOD \& Assistant Professor, Department of Mahiyatul Amraz ZVM Unani Medical College Pune, Maharashtra India.

\section{Review Paper}

Received: 31.10.2021

Revised: 12.11.2021

Accepted: 22.11.2021

ABSTRACT

Stomatitis is the inflamatory condition of mucus membrane of mouth in unani system of medicine stomatitis is known as Qula. Qula is ulceration of oral mucosal layer caused by fasaad in any one of the akhlat-e-arbah of the body first line treatment consist of topical medication with use of systemic medication as nessesary. Management of Qula in unani system of medicine , Unani physician prescribe to manage the cases of Qula by musakkin, Qabiz, mutayyib-e-dahan, mujaff-e-Qarooh mulatif, mujaffi-e-zakhm adviya.

No. of Pages: 3

References: 17

Keywords: Stomatitis, Qula, Ulcer.

\section{INTRODUCTION}

Qula (stomatitis) is an Arabic word which means blisters in the superficial layer of mucus membrane when blisters are deep seated, long lasting the termed as qaroohe khabeesa dahan. The most reknown Unani physician Ibne Sina (9821087 AD) in Alqanoon-fit-tib, described Qula as qrooh (ulcer) in the mucosal membrane of muh (buccal cavity) and zubaan (toungue) cause by fsaad. Disturbance in any one of the Akhlaat-e-Arbaa (four humerous) of the body. ${ }^{12}$

In Sharh-e-Asbaab by Samarqand(c.1222-AD) Qula is described as zakham (cut) or qarooh (ulcer) in outer most layer of mouth and it do spread in such way that it involes the whole buccal cavity and sometimes may spread in the inner mucosal layer of oesophagus and stomach resulting in pain, burning sensation. Halitosis, increased salivery secretion, thurst, white coated tounge. ${ }^{3}$

Qula (stomatitis) is defined as zakhum (ulcer) of outer and upper most layer of mucus membrane of mouth and tounge that spreads rapidly to whole of buccal cavity caused by hot vapors raised from stomach towards mouth resulting in formation of funsiya (blister) and that funsiya (blisters) in arabi is called as"Qula” when these blisters are long lasting

*Corresponding author: qazimehrosh123@gmail.com 
and deep seated then termed as "Qarooh-e-Khabeesa. stomatitis is the inflammatory condition of mucus membrane of mouth there are many types of stomatitis, among them Recurrent Apthous ulcer (RAS) is the most common found ulcer, RAS beingwell known mucosal ulcer with unclear etiopathogenesis for which symptomatic therapy is only available. The lesions are present as recurrent multiple, small or ovoid ulcers, having yellow floors and are surrounded by erythematous haloes, present first in childhood or adolescence. These small, superficial ulcers do often starts with vesicles, may develope upon the mucosal surface of lips, cheeks, tongue or palate and are usually between $2 \mathrm{~mm}$ to $3 \mathrm{~mm}$. They appear and disappear simultaniously.

\section{EITOLOGY}

In Unani literature the asbab (cause) resulting in formulation of Qula (stomatitis) as are

1. Imbalance in anyone among the akhlaat-e-arbaa. (humorous)but mostly occur due to imbalance in the safra (yellow bile). ${ }^{4}$

2. Mostly seen in breast feeding baby from the infected milk or occurs due to unhygienic oral cavity of baby most after milk feeding. ${ }^{8}{ }^{13}$

3. It mainly occur in indigestion. ${ }^{5}$

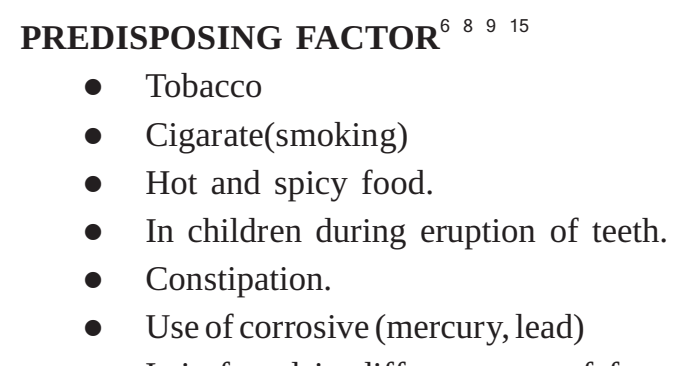

- It is found in different type of fever eg malaria, measles etc.

- It is commonly found in humid season i.e rainy season.

- In elderly person having guot.

- In some disease syphilis and gonorrhoea in which inner temperament of blood increase mostly in the late stages.

- The last stage of those disease that leads to general weakness eg TB.

\section{EITIOPATHOGENESIS ${ }^{12} 2$}

According to Abdul Hassan Ahemad bin Mohmmad Tabri in Moalijat-e-Buqratiya Qula is define as mouth wounds in which then is formation of small ulcers in mouth and toungue these ulcer occurs due to hiddat of safra in blood .

In the book of Alqanoon-fit-tib by Ibn-e-Sina it is given that qula is the qarooh (ulcer)of outer most layer of mouth in which is disturbance in anyone of the akhlaate arbaa.

\section{CLASSIFICATION OF STOMATITIS ${ }^{6,7,9,9,10,11,12,13}$}

1. Traumatic stomatitis

Simple cut or burn of the mouth which is commonly cause by vigorros use of hard tooth brush, ill fitting teeth.

2. Monilial stomatitis

It also known as thrush it is commonly caused by Fungus known as Candida albicans. It is found in infant within few weeks of life, prolong use of antibiotic in DM patient.

3. Vincent stomatitis

Also known as ulcerative stomatitis it is caused by Borrelia Vincentia which is an arobic spirochete it is mostly found in adult.

4. Angular stomatitis

It is superficial ulceration at the corner of the mouth it is found in children due to Rubbing and leaking of corner of mouth these infection caused by candid albicans and streptococci.

\section{CLINICAL FEATURES OF DIFFERENT TYPE OF QULAI DAHAN}

Damvi

This pt are having the following clinical feature

$>$ Extream pain

$>$ Burning sensation

$>$ Foul smell (halitosis)

$>$ Difficulty during mastication

$>$ Dysphagia

\section{Safravi}

$>$ Pain

Dxtream burning sensation

$>$ Dysphonia

$>$ Dyspepsia

$>$ Dysphagia

\section{Balgami}

$>$ Mild pain

$>$ Excessive salivation

$>$ Thining of oral mucosa

$>$ White coloured blisters

\section{Saudavi}

$>$ it is very rare type found this pt have following $\mathrm{c} / \mathrm{f}$

$>$ extream pain

$>$ dryness of mouth

$>$ halitosis

> on inspection the oral mucosa contain black coloured ulcer with black colour tounge 


\section{USOOLE ILAJ AND ILAJ (Line of management)}

$>$ Removal of cause

$>$ If it is caused by su-e-mizaj saada, it can be treated with taadil-e-mizaj (alteration of temperament) such as if pain is due to su-e-mizaj haar (excess of heat) then for taadil-e-mizaj (alteration of temperament) should use cold applications which is useful for restoration of health in the same way in case of su-e-mizaj barid (excessive cold) use of hot applications is beneficial

$>$ If it is caused by mawad-e-faseda, it should be treated with tanqiya-e-mawad (evacuation of vitiated or morbid matter)

Murakkab Advia (Compound formulation): ${ }^{18}$

Zaroor-e-kath, Kushta-e-Khabs-ul-Hadeed, Jawarish-eJalinoos, Habb-e-Kabidnaushaadri, Habb-e-Papeeta, (for digestive correction) Jawarish-e-Mastagi.

\section{REFRENCES}

1. Jurjani, A.H. (2010).Zakhera khawarazam shai(urdu) translation by(Hadi Hussain). New Delhi: Idara Kitabul shifa.

2. Ibn-sina (2010). Alqanun-fit-tib.(translated by Kantoori),volume $3^{\text {rd }} \mathrm{Pp}$ 674-676.

3. Qurshi, M.H. (2010) Jama-ul-Hikmat.Idara Kitabul Shifa. Pp. 668-671.

4. Samarqandi, N. (2009). Shareh Asbab(Tarjuma Kabir).Volume $1^{\text {st }}$ New Dehli: Idara Kitabul-shifa Pp.327-329.

5. Khan, M. A. (1994). Matab Amlee. New Delhi: Ejaz Publishing House. Pp. 118-112.
6. Arzani, M.A., Akseer-ul-Qaloob (urdu) New Delhi;CCRUM.Pp616-618.

7. Chandpuri. Kauser Moojiz-al-Qanoon. New Delhi; Kutub khana Anjuman-e-Taraqi-eurdu. Pp289-290.

8. Azmi, M.W. (1988) Amraz-e-uzn Wa Anaf-Wa-Halaq (1 $1^{\text {st }}$ edition) New Delhi;Ejaz publishing House. Pp134138.

9. Khan, Gj. Mukhzan-ul-Hikmat. New Delhi; Ejaz publishing House Pp.883-889.

10. Gulami jeelani (2005) Makhazan-ul-illaj. New Delhi; idara Kita-us-shifa. Pp.199-205.

11. Tabri A B R (2010) Firdosul Hikmat (translation by Mohammad Awwal Shah Sambhali) New Delhi; Idara kitab-us-shifa.Pp 67-73.

12. Multani, Tajul Hikmat. Lahor: Muluk Book depot. Pp. 95-96.

13. Kumar and Clark (2006). Clinical Medicine, $6^{\text {th }}$ edition. Elsevier Limited.

14. Greenberg M S, Pinto A., Etiology and Management of Recrent Apthuos stomatitis. Curr Infec Dis Rep. 2003. Jun; 5(3); 194-198.

15. Maurice M., Mikhaliw, Aziz M., Barsoum M. Aetiology of Recrent Aothous Ulcer (Rao) $J$ Laryngolotol, 1987 sep; 101(9), 917-920.

16. Rogers, R.S. $3^{\text {rd }}$. Recurent Apthous Stomatitis; Clinical Charactristics and evidence for an immunopathogenesis, J Invest Dematol. 1997 Dec; 69(6); 499-509.

17. Samarqandi,N. (2009). Shareh Asbab (Tarjuma Kabir). Volume $1^{\text {st }}$ New Dehli: Idara Kitabul-shifa. Pp.327-329. 